\title{
IMPLEMENTASI KNOWLEDGE MANAGEMENT PADA UMKM INDONESIA UNTUK MENINGKATKAN DAYA SAING UMKM DALAM DUNIA INTERNASIONAL
}

\author{
Setiadi Umar \\ Marketing Division and Centre of Excellence for Small Medium Enterprises studies \\ Universitas Katolik Parahyangan \\ e-mail : setiadi_u@yahoo.com
}

\begin{abstract}
It is indisputable that SMEs (Small Medium Enterprises) hold a key role in Indonesian Economic Development. Steps should be taken to increase the performance of SMEs and thus its contribution to the Indonesian economy, since a $10 \%$ increase in SMEs performance could mean a 5\% increase in Indonesian GDP. This is a significant number, remembering our GDP only increases by an average of $6 \%$ per annum. According to strategic management experts, the ability of one company to make an economic profit (an above average level of profit) depends on their ability to compete. Many pilot projects that conducted have failed and met enormous obstacles along the way. This research analyzes and highlights the condition of Innovation actors in Indonesia, who implement the knowledge management and problems in implementing knowledge management in Indonesia's environment. Therefore, it is hoped that strategic solutions can be proposed.
\end{abstract}

Keywords: implementation knowledge management, inovation, aktor inovasi Indonesia, UMKM, daya saing UMKM

\section{PENDAHULUAN}

UMKM di Indonesia, menurut Menteri Negara Urusan Koperasi dan Usaha Kecil Menengah Suryadharma Ali, memberikan kontribusi sebesar 1.778.7 trilliun atau 53.3\% dari GDP Indonesia, Peningkatan $10 \%$ dari kinerja UMKM ini berarti akan meningkatkan GDP saat ini sebesar 5\%, suatu angka yang besar, mengingat pertumbuhan GDP Indonesia saat ini hanya sekitar $6 \%$ per tahun. Di samping itu, UMKM menyerap 85,4 juta orang atau 96,18 persen terhadap seluruh tenaga kerja yang bekerja di Indonesia. Kemajuan UMKM dapat berarti pemecahan masalah bagi pengangguran di Indonesia.

Dalam salah satu halaman METI (Kementrian Perdagangan dan Industri Jepang) disebut bahwa industri kecilmenengah atau chuushoukigyou atau secara umum banyak orang mengenal dengan SME (small medium enterprise) berperan sangat besar dalam ekonomi Jepang, termasuk tentunya ekonomi-ekonomi kotanya. SME ini menyumbang $99.7 \%$ kegiatan industri Jepang, menyedot sekitar $70 \%$ sektor tenaga kerja Jepang, dengan volume penjualan mencapai 40-60\% dari keseluruhan industri. Berdasarkan data diatas, terlihat bahwa peran UMKM Indonesia, meskipun vital peranannya dalam perekonomian Indonesia, namun perannya masih tertinggal jauh dengan UMKM di negara tetangga. Sadar akan pentingnya peranan UMKM dalam suatu negara, kita perlu menanyakan langkah apa yang perlu dilakukan agar kontribusi UMKM didalam GDP menjadi makin besar, seperti negara-negara lainnya? Tindakan apa yang perlu dilakukan untuk meningkatkan kinerja dan daya saing 
UMKM terutama dalam menghadapi pasar global dan AFTA yang akan datang ini?

\section{KAJIAN TEORI}

Telah banyak bukti yang diajukan oleh para tokoh seperti Porter (1990), Romer (1990), Callon, et. al. (1992), Hakansson dan Snehota (1995), dan UNDP (2001) yang menyatakan bahwa tingkat inovasi menentukan daya saing dan kemampuan perusahaan dan industri dalam membuka pasar baru, dalam menciptakan penawaran di pasar lokal dan global serta dalam meningkatkan produktivitas perusahaan dalam mengelola sumber dayanya. Dengan menciptakan produk yang bernilai dan berdaya saing tinggi seperti ini, memungkinkan perusahaan untuk memperoleh economic profit, yaitu kemampuan perusahaan untuk memperoleh keuntungan diatas rata-rata. Hal ini berarti, perusahaan yang memiliki daya saing yang baik mampu menciptakan pekerjaan dengan penghasilan yang baik, bukan hanya cuma memperkerjakan masyarakat dengan upah minimum yang sesuai ketentuan Upah Minimum Regional (UMR).

Porter (1990) dengan diamond model nya menekankan bahwa sumber-sumber paling penting yang berkontribusi terhadap kemampuan kompetitif bukanlah faktorfaktor warisan (ineheritance) tapi diciptakan (created). Kemampuan kompetitif tersebut ditentukan oleh tingginya daya saing sebagai akibat tingginya kapasitas inovasi (innovation capacity). Kapasitas inovasi ini tidak ditentukan oleh satu aktor inovasi yang sangat inovatif saja, namun lebih ditentukan oleh interaksi yang terjadi antara aktor-aktor inovasi yang berada dalam industri tersebut. Pendapat ini juga didukung oleh Freeman (1996) yang mengatakan bahwa inovasi jangan dipandang sebagai proses yang linear, baik itu berawal dari kondisi permintaan, ataupun dari kemajuan teknologi, namun lebih merupakan hasil dari interaksi yang kompleks yang menghubungkan pengetahuan yang baru dengan pemakai pengetahuan. Niosi et. al. (1993), Freeman (1996), Porter (1990), UNDP (2001), Senker (1996), Bell and Pavitt (1997), juga menyiratkan bahwa keberadaan interaksi antara perusahaan dan perusahaan pendukungnya, universitas, pemerintah, organisasi riset, dan organisasi finansial, tersebutlah sumber utama pengetahuan yang mendorong dan menjadi dasar penciptaan pengetahuan dan inovasi yang baru.

Penelitian Jensen (2007) di Kerala, India menemukan bahwa dengan meningkatnya arus pertukaran informasi tentang harga yang sederhana dan hanya didukung oleh teknologi telepon selular, menghasilkan pasar yang lebih efektif. Sejak diperkenalkannya telepon selular, keuntungan nelayan naik $8 \%$, volatilitas harga menurun dan harga rata-rata ikan sardin yang dijual kepada konsumen juga turun sebesar 4\%, disamping itu juga terjadi penghentian beberapa praktek yang tidak meningkatkan nilai jual seperti membuang ikan kembali ke laut.

Berdasarkan penelitian lain, yang dilakukan oleh Waverman et. al. (2007) menemukan bahwa penambahan 10 orang pengguna telepon selular per 100 orang, menghasilkan peningkatan sebesar $0.59 \%$ pada GDP percapita. Makin pentingnya pertukaran informasi ini membuat beberapa ahli teknologi informasi dan manajemen mempelajari apa yang disebut knowledge management, yang dapat dikatakan mengelola dan membagi informasi secara sadar melalui system teknologi yang dapat mempermudah pencarian informasi, sehingga dapat memperkaya ilmu-ilmu yang telah dimiliki oleh seseorang. Dengan demikian suatu keilmuan dan inovasi menjadi dapat berkembang, dan manusia tidak perlu bersusah payah untuk menemukan roda untuk ke dua kalinya 
terutama bila roda tersebut pernah ditemukan oleh orang lain.

Berdasarkan paparan di atas sudah jelas terlihat bahwa kemajuan masa depan dibangun bukan lagi hanya mengandalkan sumber daya alam, melainkan modal maya (virtual capital) yaitu adalah intellectual capital, social capital, ethical capital, dan semangat yang tercipta dari interaksi antar aktor inovasi dan juga knowledge yang dimiliki oleh para aktor inovasi, yaitu sumber daya manusia.

\section{HASIL KAJIAN}

Kondisi Aktor Inovasi Indonesia.

Di samping pembahasan mengenai knowledge management (KM), yang mengelola interaksi antara aktor-aktor inovasi, akan dibahas juga tentang siapa, tingkat kesiapan, kondisi serta tantangan yang dihadapi oleh pelaku inovasi tersebut. Mengikuti yang telah diidentifikasi oleh para tokoh di atas, yang dimaksud dengan pelaku/aktor inovasi disini adalah: industri (termasuk UMKM), institusi pendidikan, pemerintah, institusi keuangan, dan institusi riset. Para pelaku inovasi ini memiliki peran vital dalam KM karena merekalah pelaku, pencari, pensortir, pengklasifikasi sekaligus penyumbang pengetahuan. Hal-hal yang dapat meningkatkan kualitas knowledge yang dimiliki oleh aktor-aktor inovasi ini berarti meningkatkan kualitas KM yang terbentuk. Hal ini perlu disadari agar dapat dibuat strategi pengembangan yang efektif yang berfokus pada peningkatan kualitas dan kemampuan dari aktor inovasinya juga selain pada KM yang akan dibentuk. Sehingga tidak terjadi GIGO (garbage in garbage out) atau orang buta yang menuntun orang buta yang lain dalam KM yang dibuat kelak. Oleh karena itu perlu dikenali karakteristik dari aktor-aktor inovasi yang ada, faktor-faktor yang mempengaruhi kualitas knowledge aktoraktor inovasi Indonesia, tantangan yang perlu dihadapi dan gap yang perlu ditutup dan diperbaiki untuk meningkatkan faktorfaktor tersebut. Karena yang namanya KM lebih dari hanya sekedar taktik untuk mengimplementasikan software dan hardware kepada UMKM.

\section{Kondisi Perusahaan-perusahaan di Indonesia Saat Ini.}

Saat ini, penjualan produk Indonesia di pasar global, mayoritas masih dikuasai oleh perusahaan komoditi, yaitu perusahaan yang profitnya tergantung pada volatilitas harga yang terjadi di pasar dan tidak dapat menentukan harga sendiri. Disamping itu, kinerjanya sangat tergantung dari alam (karena perusahaan ini sangat tergantung pada faktor-faktor yang bersifat inheritance). Perusahaan komoditi menyumbang $65.38 \%$ (BPS, 2007) dari ekspor Indonesia, dan bila kita memasukan barang-barang ekspor yang sebagian besar biayanya berupa biaya input barang komoditas, maka angka ketergantungan ini meningkat menjadi $80 \%$ (Cashmore, 2007).

Minimnya perusahaan internasional Indonesia yang mengandalkan produk yang nilainya dihasilkan oleh faktor-faktor "created", seperti nike contohnya dan bukan tergantung pada faktor-faktor yang "inherited" adalah tidak mengherankan. Karena kondisi daya saing perusahaan-perusahaan di Indonesia memang jauh ketinggalan dibandingkan dengan perusahaanperusahaan yang terdapat di negara lain. Berdasarkan IMD World competitiveness yearbook 2007, pada tahun 2003 daya saing perusahaan Indonesia menempati posisi ke 49 dari 55 negara yang disurvey. Kondisi ini terus menurun di tahun tahun berikutnya menjadi peringkat ke 50 di tahun 2005, 52 di tahun 2006, dan 54 di tahun 2007.

\section{Kondisi Kompensasi}

Kondisi seperti ini, akhirnya tidak hanya membatasi gaji yang dapat diberikan 
perusahaan namun juga menimbulkan stagnasi gaji. Hal ini berarti setiap tahun pekerja membawa penghasilan yang makin lama makin kecil. Berdasarkan riset yang dilakukan oleh CLSA mengungkapkan bahwa pada lima tahun terakhir ini, penghasilan riil rata-rata tumbuh sebesar negatif 2\% (Cashmore, 2007). Bahkan untuk beberapa industri, seperti pada industri keramik, lebih buruk. Kondisi ini tentu saja berarti makin terbatasnya uang yang dapat dikeluarkan untuk melakukan konsumsi, dan termasuk diantaranya adalah pengeluaran untuk pendidikan. Kondisi ini tentu berperan juga sebagai salah satu penyebab meningkatnya jumlah orang miskin. Berdasarkan data BPS, orang miskin di Indonesia telah mencapai 37.1 juta orang atau $16.58 \%$ dari jumlah seluruh populasi atau meningkat sebanyak $75 \%$ dari angka 21.1 juta di tahun 2002 (BPS, 2007).

\section{Kondisi pendidikan}

Pada tahun 2000, OECD (2003) mengadakan PISA (Programme for International Student Assessment), suatu program yang diadakan untuk menguji kemampuan siswa dalam belajar. Hal yang diuji oleh PISA adalah, kemampuan siswa untuk melakukan analisa, argumentasi, dan mengkomunikasikan secara efektif atas apa yang telah mereka pelajari ketika mereka menghadapi, memecahkan dan menterjemahkan berbagai masalah dalam berbagai macam situasi. Berdasarkan hasil PISA yang terakhir, tahun 2003, dari 41 negara, Indonesia menempati posisi di bawah. Finlandia yang meraih urutan teratas menunjuk bahwa sistem sekolah dan kurikulum merekalah yang menjadi penyebab kemenangan mereka.

Tidak hanya itu, 59.87\% (BPS, 2006) dari populasi indonesia yang berumur lebih dari 10 tahun belum melewati pendidikan SD. Bahkan menurut data yang didapat dari penelitian Bambang Setiarso di tahun 2001, menunjukkan bahwa $65.3 \%$ dari pengusaha nonformal berpendidikan SD kebawah dan hanya $1.6 \%$ yang berpendidikan sarjana muda atau diploma III keatas. Sekedar informasi 75\% (Cashmore, 2007) dari penduduk Indonesia bergerak di sektor non formal. Pada sektor industri pengolahan pangan juga tidak menunjukan gambaran yang lebih baik. Sebagian besar dari jumlah pengusaha kecil di sektor tersebut yang maksimum berpendidikan SD mencapai angka $80 \%$, dan yang berpendidikan tersier (DIII/Sarjana Muda) keatas, kurang dari 1 $\%$. Bila data ini masih dapat diandalkan pada masa sekarang ini, maka hal ini berarti penerimaan / adaptasi proses pembaharuan dalam UMKM akan menjadi lebih sulit. Kesulitan dapat timbul dari masalah dalam pemahaman bahasa, istilah, dan komunikasi, dimana hal-hal ini akhirnya akan menyulitkan pemahaman dan penguasaan teknologi yang diperlukan itu sendiri.

\section{Kondisi Pengembangan Teknologi di Indonesia}

Indonesia termasuk salah satu negara dengan tingkat pengeluaran R\&D yang terkecil dibandingkan negara-negara tetangga kita. Pengeluaran untuk R\&D kita hanya sebesar $0.1 \%$ dari GDP kita atau 0.3 milyar dollar US, dan sangat terpusat pada pemerintah baik pembiayaan maupun pelaksanaannya. Hanya $14.7 \%$ hasil R\&D yang dihasilkan oleh bisnis dan hanya $4.6 \%$ yang dihasilkan oleh universitas. Namun meskipun Indonesia termasuk yang terbawah dalam pengeluaran untuk $R \& D$, tapi berdasarkan data dari WIPO (2007), produktifitas biaya R\&D Indonesia, adalah yang terbaik dibandingkan negara lain. Setiap 1 juta dollar yang dikeluarkan untuk keperluan, R\&D, menghasilkan 10 patent yang diajukan. Sayang angka produktifitas yang besar ini, tidak diikuti oleh jumlah patent yang dihasilkan. Menurut catatan WIPO (2007), hanya 60 buah paten 
Indonesia yang masih berlaku di tahun 2005 dan hanya 17 paten yang diajukan untuk setiap 1 juta penduduk Indonesia, persentase rasio yang jauh lebih rendah daripada yang dihasilkan oleh negara-negara tetangga kita.

\section{Kondisi Permodalan dan Institusi Keuangan}

Berdasarkan catatan dari Bank Indonesia, perbankan mengalami kelebihan dana ditunjukan dengan perbedaan yang makin besar dari tahun ke tahun antara jumlah simpanan masyarakat (dana pihak ketiga) yang dimiliki oleh perbankan dan jumlah yang dikucurkan untuk kredit (lihat Tabel 1).

Hal ini dapat diartikan kurangnya atau susahnya permintaan akan kredit, atau dapat pula diartikan tersedianya cukup dana untuk mengakomodir naiknya permintaan kredit yang meningkat yang disebabkan oleh biaya modal yang terus menurun.

Di samping itu, data lain yang perlu diperhatikan adalah data tentang BPR (Bank
Perkreditan Rakyat). Bila BPR akan dijadikan tulang punggung pembiayaan UMKM maka data pertama yang perlu diperhatikan adalah penyebaran BPR, karena penyebarannya di luar jawa-bali dan Sumatra, masih sangat kurang. Kedua, data yang perlu diperhatikan adalah ketidak merataan tingkat NPL (non performing loan) dan LDR (loan to deposit ratio) di berbagai daerah. Dimana tingginya NPL mencerminkan resiko yang lebih tinggi dalam UMKM. Musim masuk sekolah atau karena istri melahirkan merupakan salah satu dari sekian penyebab gagal bayar yang umum terjadi. Sedangkan tingkat LDR yang rendah, dapat mencerminkan ketidak tahuan masyarakat tentang fungsi perbankan sebagai penunjang usaha. Yang terakhir adalah data permintaan kredit BPR. Berdasarkan data permintaan kredit BPR, permintaan kredit untuk keperluan investasi masih sangat kecil.

Tabel 1: Simpanan Masyarakat (Bank Indonesia, 2007)

\begin{tabular}{|c|c|c|c|}
\hline Tahun & $\begin{array}{l}\text { Dana Pihak Ketiga } \\
\text { (trilliun rupiah) }\end{array}$ & $\begin{array}{c}\text { Kredit } \\
\text { (trilliun rupiah) }\end{array}$ & $\begin{array}{c}\text { LDR } \\
\text { (persen) }\end{array}$ \\
\hline 1997 & 358 & 378 & 106 \\
\hline 1998 & 573 & 487 & 85 \\
\hline 1999 & 626 & 225 & 36 \\
\hline 2000 & 720 & 269 & 37 \\
\hline 2001 & 809 & 308 & 38 \\
\hline 2002 & 836 & 410 & 49 \\
\hline 2003 & 902 & 477 & 53 \\
\hline 2004 & 963 & 595 & 62 \\
\hline 2005 & 1128 & 730 & 65 \\
\hline 2006 & 1287 & 833 & 65 \\
\hline $2007 *$ & 1354 & 904 & 67 \\
\hline
\end{tabular}

*Juni 
Kondisi Keberadaan Teknologi Informasi di Indonesia.

Dari hasil Susenas 2005, hanya 7.7 juta dari 58.8 juta rumah tangga $(13.11 \%)$ yang memiliki telepon rumah, dan angka ini lebih kecil sedikit dari jumlah pemilik telepon selular yaitu 11.7 juta rumah tangga (19.96\%). Sebagian besar dari angka ini, yaitu sebanyak 6.6 juta orang pemilik telpon rumah dan 9.0 juta pemilik telepon selular tinggal di daerah perkotaan. Dari 58.8 juta rumah tangga keseluruhan, hanya $3.68 \%$ yang memiliki komputer, dan dari angka $3.68 \%$ ini, hanya $27 \%$ nya yang menggunakannya untuk akses internet. Dari 58.8 juta rumah tangga hanya 3,66\% yang pernah melakukan akses internet baik dari warnet, kantor, sekolah dan lainnya.

\section{Kendala pengembangan KM dalam UMKM}

Setelah melihat kondisi dari pelaku inovasi, marilah kita melihat bagaimana hasil langkah- langkah pengembangan KM dalam UMKM yang telah dilaksanakan seperti dibentuknya SME centre, serta berbagai inkubator bisnis lainnya, sejauh ini. Menurut Deperindag, ada beberapa masalah yang telah teridentifikasi dan perlu diperhatikan. Menurut catatan Deperindag, permasalahan dalam penerapan/pengembangan iptek di UMKM dapat dikelompokan dalam dua kategori, yaitu masalah internal atau masalah yang dapat dipengaruhi oleh pengusaha, dan masalah eksternal atau masalah yang bagi pengusaha adalah given.

Masalah-masalah internal antara lain, 1) Kesadaran dan kemauan pengusaha untuk menerapkan ilmu pengetahuan dan teknologi tepat guna di perusahaan masih sangat terbatas. 2) Keterbatasan modal untuk melakukan perbaikan/peningkatan teknologi. 3) Kurangnya kemampuan pengusaha untuk memanfaatkan peluang usaha. 4) Lemahnya akses dan terbatasnya informasi tentang sumber teknologi dan pengetahuan tertentu.

Sedangkan masalah-masalah eksternal adalah, 1) Sebagian besar hasil litbang yang ada hingga saat ini bukan yang diperlukan oleh UMKM. 2) Proses alih teknologi kepada UMKM belum optimal, antara lain keterbatasan tenaga pendamping di lapangan. 3) Publikasi hasil-hasil litbang masih terbatas dan penyebarannya belum menjangkau UMKM di seluruh wilayah. 4) Skim pembiayaan untuk pengembangan ilmu pengetahuan dan teknologi termasuk pembelian mesin-mesin baru untuk UMKM masih terbatas. Misalnya masalah leasing dan sewa beli masih terbatas, dan belum banyak dimanfaatkan oleh UMKM karena tidak kompetitif.

Oleh karena itu dapat dikatakan bahwa salah satu penyebab kinerja UMKM di Indonesia jauh lebih rendah dibandingkan kinerja UMKM di negara-negara maju, adalah masih rendahnya pengembangan atau penguasaan pengetahuan dan teknologi oleh aktor-aktor inovasi di Indonesia. Daya saing perusahaan-perusahaan Indonesia yang rendah, kompensasi yang rendah, keberadaan sarana dan prasarana yang tidak memadai, kondisi permodalan yang tidak disertai dengan kredit investasi, dan tingkat pendidikan yang rendah, semuanya mempengaruhi kinerja UMKM dan pengembangan UMKM yang ada di indonesia.

Disamping itu, kondisi ini juga mempersulit penerapan KM pada UMKM. Karena semua faktor diatas akan mempengaruhi kualitas interaksi yang terjadi, serta kemudahan interaksi antar faktor inovasi. Masalah penerapan KM pada UMKM ini makin dipersulit dengan kondisi topografi Indonesia yang berbentuk kepulauan, beragamnya budaya serta bahasa, sedikitnya lulusan pergurusan tinggi yang ada, jumlah dan kualitas guru yang ada, rendahnya kualitas kurikulum kita (menurut PISA), serta sedikitnya jumlah pengusaha 
UMKM yang mampu menyerap kemampuan teknologi, dan fasih berbahasa lain kecuali bahasa daerahnya sendiri. Semua ini makin menyulitkan penyebaran pengetahuan.

Namun meskipun terdapat berbagai kendala dan tantangan diatas, bukan berarti tidak ada harapan. Berbagai perbaikan perlu dilakukan, sehingga dapat dibentuk KM yang tidak hanya sekedar memudahkan interaksi antar pelaku inovasi, yaitu antara institusi riset, pendidikan, industri, pemerintah dan keuangan, namun interaksi yang terjadi dapat menjadi interaksi yang terarah pada pengembangan kemampuan $\mathrm{R} \& \mathrm{D}$, pengembangan Bisnis dan SDM itu sendiri.

\section{KM yang Bernuansa User Friendly dan Bernuansa Lokal}

Sebenarnya permasalahan yang pertama kali harus dipecahkan sebelum kita dapat menerapkan KM pada UMKM Indonesia adalah membuat KM dalam bentuk yang mudah dikomunikasikan, sederhana dan mudah dimengerti oleh UMKM di Indonesia. Rendahnya tingkat pendidikan diiringi dengan beragamnya bahasa, dialek dan budaya Indonesia, memberikan tantangan tersendiri dalam usaha implementasi KM tersebut.

Sarana dan prasarana yang digunakan baik dalam memperoleh maupun membagi pengetahuan juga perlu diperhatikan. Akan lebih baik bila menggunakan sarana dan prasarana yang telah mereka kenal, atau dalam bentuk lain yang mereka inginkan. Penggunaan sarana yang "user friendly" seperti telepon seluler, rembuk desa /sharing, mentoring oleh tenaga ahli, merupakan hal yang perlu dipertimbangkan.

Bila kita hendak menggunakan internet pada tahap awal ini perlu disediakan operator komputer yang mengerti internet, yang menguasai bahasa lokal, serta bahasa yang dipakai oleh aktor inovasi secara umum. Sehingga operator internet ini dapat menerjemahkan dengan baik permasalahan, keluhan, pertanyaan, serta pengetahuan dari UMKM lokal dan meneruskannya ke pusat data base/knowledge centre. Disamping itu juga mampu meneruskan keterangan yang didapat dari pusat data base kepada aktor lokal yang membutuhkan dengan bahasa yang sehari-hari yang mudah dimengerti baik tujuan maupun isinya, sehingga bisa diterapkan dan tidak membingungkan.

Penggunaan operator lokal ini penting, karena akan lebih sulit untuk mendidik seseorang yang hanya lulusan SD atau dibawahnya untuk mengerti tentang database, mencari data via internet atau berhubungan dengan komputer, akan lebih mudah untuk langsung menerangkan kepada mereka, sebaiknya pada musim kapan untuk menanam, atau bagaimana memilih bibit yang berkualitas, cara menangkap ikan yang baik, dan lain sebagainya serta apa keuntungan yang diperoleh dengan mempraktekan cara baru tersebut. Disamping itu, akan lebih mudah bagi operator lokal yang telah mengetahui nuansa, bahasa lokal, dan bahasa umum sekaligus untuk menterjemahkan apa yang dimaksud oleh pengusaha lokal yang mungkin kurang mendapatkan pendidikan formal baik itu dalam bentuk pertanyaan ataupun sharing pengetahuan, dibandingkan dengan profesor yang berdomisili di jakarta yang sama sekali tidak tahu menahu budaya lokal untuk mengerti, menerjemahkan atau menangkap apa yang dimaksud oleh aktor lokal tersebut.

Pemberian ilmu/transfer knowledge harus dilakukan dengan cara yang sederhana dan kental dengan suasana lokal, agar mudah dimengerti atau dapat terjadi kesalah pahaman, baik ketika aktor inovasi yang lain berusaha menerjemahkan pengetahuan/pertanyaan yang diberikan oleh pengusaha lokal atau terjadi sebaliknya. Bila hal ini terjadi, pertukaran informasi akan menjadi sesuatu yang sangat sulit, membuat frustasi, apalagi mengembangkannya. 
Disamping penyediaan sarana dan prasarana KM, yang tidak kalah pentingnya adalah sosialisasi KM kepada aktor-aktor inovasi agar KM tersebut digunakan. Sosialisasi KM ini, selain perlu menyampaikan kegunaan dari KM itu bagi aktoraktor inovasi secara jelas, sosialisasi ini harus perlu disampaikan dengan jelas, sederhana, dan juga bernuansa lokal.

\section{Pembiayaan Sarana dan Pra Sarana}

Luasnya daerah Indonesia, dan banyaknya sarana dan pra sarana yang perlu dibangun, tidak memungkinkan untuk menyerahkan pembangunan ini untuk seluruhnya ditanggung oleh negara. Disamping itu, Bila hal ini terjadi, akan menimbulkan lebih banyak dampak negatif dibandingkan dampak positif. Yang pertama adalah kemajuan UMKM apalagi yang berlokasi di pelosok Indonesia harus menunggu waktu yang sangat lama, karena terbatasnya dana APBN yang tersedia. Yang kedua, pembangunan akan mengikuti skala prioritas dan bukan karena perkembangan pasar, sehingga dapat terjadi ketimpangan pembangunan. Yang Ketiga biaya pembangunan yang terjadi dapat menjadi sangat besar, karena ada kemungkinan biaya "tambahan" yang dikenakan oleh oknumoknum tertentu baik dari kontraktor, pemerintahan maupun dari perbankan. Yang keempat adalah adanya kemungkinan bahwa apa yang dibangun bukanlah apa yang benar -benar diperlukan oleh masyarakat lokal tersebut (seperti apa yang telah terjadi dalam kasus R\&D di negara kita. R\&D yang terpusat pada pemerintah, menghasilkan banyak hasil R\&D yang ternyata tidak dibutuhkan oleh dunia usaha) dan yang terakhir adalah, bila proyek-proyek tersebut dibiayai oleh pinjaman luar negeri, dapat membuat negara kita terpuruk ke dalam hutang luar negeri, seperti yang pernah terjadi pada periode yang lalu.
Oleh karena itu, pembangunan sarana dan pra sarana ini akan jauh lebih baik bila memasukan unsur swasta kedalamnya. Hal ini tidak berarti peran pemerintah dapat berkurang, atau dapat lepas tangan dari pembangunan sarana dan prasarana ini. Peran pemerintah sebagai regulator dan pemberi insentif masih diperlukan untuk menciptakan suasana dan kondisi yang kondusif yang dapat menarik sektor swasta untuk bergerak dibidang tersebut. Pemberian kredit lunak, pemotongan pajak, kepastian hukum, pemberantasan pungli, hanyalah sedikit dari banyak hal yang dapat dilakukan pemerintah untuk meningkatkan suasana investasi.

Namun bagaimana kita bisa membuat perusahaan-perusahaan ini membangun ke daerah-daerah yang kurang menguntungkan? Memang, mungkin akan sangat mahal untuk membuat jaringan internet di seluruh indonesia, membangun jalan dan komunikasi, listrik ke seluruh pelosok Indonesia, namun tidak terlalu mahal biaya yang dibutuhkan untuk membuat sebuah internet cafe, sebuah tower Base Transceiver Station (BTS), untuk membangun $10 \mathrm{~km}$ jalan raya, dan sebuah generator sederhana. Dimana semua ini dapat ditanggung oleh seorang, atau beberapa orang wirausahawan yang berjiwa wirausaha yang dapat mendapatkan keuntungan dari sana yang mungkin kecil di saat ini, tapi dapat meningkat ketika perekonomian daerah tersebut meningkat.

Dengan adanya jalan raya, dan komunikasi, akan membuat petani dapat menjual hasil usahanya di pasar yang lebih jauh, dengan harga yang lebih tinggi. Dengan adanya Pembangkit listrik, Pabrik sederhana/home industries dan UMKM lainnya dapat berkembang, hasil alam dapat ditingkatkan nilainya, pengetahuan bisa lebih gampang diperoleh. Hal ini berarti peningkatan ekonomi. Dengan adanya pertumbuhan ekonomi, berarti dapat 
mengembangkan desa itu lebih lanjut, lebih banyak UMKM yang dibuat, UMKM yang ada menjadi lebih efisien, dan mungkin setelah itu terdapat permintaan atau kebutuhan akan sarana dan prasarana yang lebih maju. Pengusaha UMKM dapat meningkatkan daya dari pembangkit listriknya, BTS dapat ditambah, jalan diperlebar, bahkan mungkin sudah waktunya untuk memulai membangun fasilitas lain seperti lapangan terbang sederhana atau pelabuhan yang sesuai dengan kebutuhan dan untuk menunjang pertumbuhan ekonomi lebih lanjut. Hal yang sederhana ini dapat menjadi besar, bila di setiap desa dan setiap UMKM terdapat semangat berusaha dan berinovasi seperti ini. Dengan demikian perkembangan, tidak hanya dirasakan oleh masyarakat perkotaan.

Dengan adanya potensi keuntungan, baik itu yang segera terjadi atau yang akan terjadi dengan adanya sarana dan prasarana, berarti terdapat permintaan untuk fasilitas tersebut. Dan bila diiringi dengan biaya pendirian fasilitas sederhana seperti pendirian sebuah BTS atau generator sederhana yang dapat dijangkau oleh pengusaha, seharusnya dapat menjadi insentif yang kuat bagi para wirausahawan dan atau bagi para pemakai (yang akan mendapatkan keuntungan tersebut) untuk mendirikan fasilitas tersebut. Pembangunan sarana dan prasarana ini dapat diorganisir dan ditanggung secara bersama-sama oleh sesama pemakai atau juga bisa dibantu oleh investor/entrepreuner yang lain dan mungkin juga dengan pemerintah daerah (pemda) bila mungkin. Disini berarti pemakai, selain juga bertindak sebagai pembeli/pengguna, dapat juga bertindak sebagai pemegang saham/pemilik fasilitas. Selain itu, di daerah yang asas kegotong royongannya masih kuat, dapat mendorong biaya pendirian fasilitas ini menjadi makin terjangkau.

Disamping peranannya dalam pembangunan ekonomi, sarana dan pra sarana ini, seperti BTS, listrik, dan internet cafe, juga dapat memberikan penghasilan dan keuntungan bagi dirinya sendiri, dimana keuntungan ini dapat ditahan untuk ekspansi selanjutnya atau dibagikan kembali sebagai deviden kepada para pemegang sahamnya.

\section{Dukungan institusi keuangan}

Hanya saja, hal ini tentu tidak terlepas dari masalah pembiayaan dan kemudahan mendapatkan dana. Ketersediaan institusi keuangan unit khusus yang diperuntukan untuk pengembangan UMKM seperti Bank Perkreditan Rakyat (BPR) dan koperasi, yang mengenal kondisi lokal, sangat diperlukan untuk mendukung inovasi dan pengembangan usaha UMKM di daerah. Hal ini bahkan telah menjadi masalah yang telah diidentifikasi oleh Deperindag yang menyatakan bahwa salah satu masalah pengembangan/penerapan iptek di UMKM adalah keterbatasan modal dan pembiayaan baik untuk permesinan, tenaga ahli, dan untuk pembangunan sarana dan pra sarana pertukaran informasi dan perhubungan yang masih sangat minim.

Kebutuhan untuk memperoleh dana secara mudah berarti membutuhkan ketersediaan unit-unit khusus pembiayaan tersebut di daerah-daerah. Hal ini berarti penyebaran BPR, meskipun sudah cukup baik di pulau jawa, masih perlu diperluas di pulau-pulau lainnya, karena keberadaannya masih sangat terbatas.

Lebih dari itu, dengan keberadaan peta NPL (non performing loan) \& LDR (loan to deposit ratio) dari BPR ini dapat menjadi panduan bagi BI untuk mengidentifikasi dan memprioritaskan, daerahdaerah mana yang masih memerlukan pendidikan terutama di bidang bisnis, perbankan, keuangan, dan manajemen untuk UMKM. Sehingga dapat menghasilkan pengusaha-pengusaha UMKM yang berwawasan bisnis yang profesional dan dapat memisahkan antara untuk kebutuhan bisnis 
dan untuk kebutuhan keluarga. Dengan demikian tingkat NPL dapat dikurangi dan dengan turunnya tingkat NPL ini, persepsi akan resiko atas pemberian kredit pada UMKMpun dapat menurun. Dengan turunnya tingkat persepsi akan resiko UMKM ini, dapat berarti biaya modal yang dikenakan untuk daerah tersebut dapat diturunkan dari tarif rata-rata yang berlaku pada saat ini, yaitu $24 \%$.

Namun, tidak hanya itu peran BPR. Kredit investasi, kredit yang dapat menggerakkan sektor riil, yang diberikan oleh BPR saat ini, masih dalam porsi yang terlalu kecil, dibandingkan kredit jangka pendek dan kredit konsumtif. Perlu diambil langkah-langkah yang dapat meningkatkan hal ini sehingga dengan demikian dengan turunnya suku bunga tidak hanya meningkatkan kredit konsumsi, namun juga kredit investasi. Pengajuan kredit investasi perlu dipermudah. Disamping itu perlu diperhatikan bahwa dari 43 juta unit UKM, hanya $13 \%$ yang bankable (memiliki jaminan) dan dapat mengajukan kredit investasi. Sehingga perlu dipikirkan bentuk lain yang dapat digunakan untuk pembiayaan investasi ini, seperti bentuk leasing dan sewa beli misalnya. Dimana pada kredit jenis ini, barang yang dibeli, selain berguna untuk keperluan usaha, juga dapat dipergunakan sebagai jaminan. Di samping itu pengarahan bahwa perbankan tidak hanya dapat digunakan untuk mengatasi masalah konsumsi dan keperluan jangka pendek, tetapi dapat juga digunakan sebagai penunjang kepentingan usaha juga, dapat dilakukan.

\section{PENUTUP}

Dalam usaha pengembangan teknologi Indonesia pun dapat mengikuti cara yang hampir sama yang telah dijawabarkan diatas, yaitu dengan memasukkan peran swasta. Dengan banyaknya agenda yang perlu dipenuhi oleh APBN, peran R\&D akan terus terbatas bila hanya mengandalkan pada apa yang dilakukan pemerintah, selain itu hasil litbangnya tersebut dinilai kurang sesuai dengan apa yang dibutuhkan. Dengan meningkatnya peran serta dari swasta, akan secara otomatis meningkatkan dana yang diperuntukan untuk R\&D sekaligus meningkatkan porsi swasta dalam R\&D. Disamping itu R\&D yang dihasilkan akan lebih sesuai dengan apa yang dibutuhkan dunia usaha. Pemberian insentif, grant, dan sosialisasi paten kepada pihak swasta, merupakan langkah yang perlu dipertimbangkan.

Penguatan aktor inovasi dapat menjadi prasyarat vital dalam pelaksanaan KM yang baik. Investasi dalam pengembangan SDM, dan membuat sumber daya tersebut lebih dapat berpartisipasi dalam pertumbuhan ekonomi, dan menjadi salah satu partisipan KM yang kreatif, adalah sangat vital. Seperti yang telah dibahas diatas, kemajuan masa depan dibangun bukan lagi hanya mengandalkan sumber daya alam, melainkan modal maya (virtual capital). Dan Bangsa Indonesia masih tertinggal jauh dalam hal pendidikan.

Pengusaha UMKM harus dibekali dengan business sense, yang memungkinkan dia mengelola usahanya dengan lebih profesional, dan dapat menangkap peluang untuk mengembangkannya. Untuk itu, Tidaklah cukup andaikata kita hanya memberikan ilmu yang dapat meningkatkan produktifitas atas apa yang dikerjakannya sekarang. Ilmu yang lebih luas seperti ilmu hukum, bisnis, keuangan, manajemen, manajemen SDM, dan pemasaran perlu diberikan, meskipun dalam bentuk yang sederhana. Pengusaha harus dibekali pengetahuan yang cukup agar tidak perlu menjalani trial dan error yang menyakitkan untuk menemukan roda yang ke dua kalinya. Perlu diambil langkah-langkah dan strategi yang dapat mengembalikan para sarjana/orang pintar ke desa. Baik untuk 
mengembangkan KM pada UMKM pedesaan, melakukan mentoring maupun untuk mengembangkan perekonomian pedesaan itu sendiri. Kebutuhan akan sarjana seharusnya tidak hanya menjadi monopoli orang kota.

Di samping itu, ketersediaan sarana dan prasaranapun harus diperhatikan. Ketidak tersediaan sarana dan prasarana dpat menyebabkan bisnis tidak dapat dilaksanakan secara efektif dan efisien. Namun karena terbatasnya kas negara dan banyaknya agenda negara, menyebabkan kita tidak dapat menggantungkan pembuatan sarana dan prasarana ini kepada negara, karena opportunity cost yang ditanggung sangatlah besar. Dengan menunggu uluran tangan negara, berarti akan membuat kita makin jauh tertinggal (terutama dalam bidang teknologi) dan dengan begitu memperlambat proses roda ekonomi. Sementara, yang namanya teknologi, inflasi, dan pertumbuhan penduduk, sama sekali tidak berhenti bertumbuh dan berkembang. Oleh karena itu perlu dicari alternatif pembiayaan yang lain, yaitu sektor swasta. Akhir kata, kita harus melihat KM lebih dari sekedar taktik untuk mengimplementasikan software dan hardware kepada UMKM. Namun termasuk didalamnya, menarik para aktor inovasi untuk berpartisipasi, berkembang, dan hal ini berarti adanya relasi jangka panjang yang harus dibina.

Namun untuk mewujudkan hal ini pertama-tama diperlukan sistem komunikasi dan pemasaran yang baik yang dapat menarik dan meningkatan peran serta dari aktor inovasi itu sendiri, sehingga sharing dan transfer knowledge dapat berjalan lancar.

\section{DAFTAR PUSTAKA}

Bank Indonesia (2007). Cetak Biru Bank Perkreditan Rakyat.
Bell, M. and Pavitt, K. (1997). Technological accumulation and industrial growth: contrasts between developed and developing countries, in D. Archibugi and J. Michie (eds). Technology, Globalisation and Economic Performance. Pp. 83137. Cambridge: Cambridge University Press.

Badan Pusat Statistik-BPS. (2006). Berita Resmi statistik. 14 Agustus 2006

Badan Pusat Statistik-BPS. (2005). Berita Resmi statistik. 1 Mei 2007.

Callon, M., Laredo, P. and Raberharisoa, V. (1992). The management and evaluation of technological programs and the dynamics of technoeconomic networks: the case of the AFME. Research Policy, 21, 215236.

Cashmore, N. (2007). Indonesia Market Outlook. CLSA, 15 Agustus 2007.

Freeman, C. (1996). The greening of technology and models of innovation. Technological Forecasting and Social Change, 53, 27-39.

Hakansson, H., and Snehota, I. (1995). Developing Relationships in Business Networks. London: Routledge.

Jensen, R. (2007). The Digital Divide: Information (technology), market performance and welfare in the South Indian fisheries sector, Quarterly Journal of Economics, August 2007.

Niosi, J., Saviotti, P., Bellon, B. and M. Crow. (1993). National Systems of Innovation: In Search of A Workable Concept. Technology in Society, 15 (2), 207-227. 
Porter, M.E. (1990). The Competitive Advantage of Nations. New York: Free Press.

Romer, P.M. (1990). Endogenous Technological Change. Journal of Political Economy, 98 (October), S71-S102.

Senker, J. (1996). National systems of innovation, organizational learning and industrial biotechnology.

Technovation, 16 (5), 219-229.

UNDP (2001). Human Development Report 2001: Making new technologies work for human development. New York: UNDP.

WIPO (2007). WIPO Patent Report: Statistics on Worldwide Patent Activity, 2007 Edition published, 10 Agustus 2007. 